\title{
УДК 657.1
}

Редченко К. I., redchenko@ukr.net, ORCIDID:0000-0001-8234-4074, Researcher ID: F-3039-2013, д.е.н., проф., професор кафедри обліку, контролю, аналізу та оподаткування, Львівський торговельно-економічний університет, м. Львів

Чік М. Ю., marija_chik@ukr.net, ORCID ID:0000-0002-8124-2276,

Researcher ID: Y-3059-2018, к.е.н., доц., доцент кафедри обліку, контролю, аналізу та оподаткування, Львівський торговельноекономічний університет, м. Львів

\section{ЗВЕДЕНИЙ ОБЛІК ВИТРАТ ЯК СКЛАДОВА ФОРМУВАННЯ РЕЗУЛЬТАТУ ДІЯЛЬНОСТІ ПІДПРИЕМСТВА}

\begin{abstract}
Анотація. У статті досліджено проблему повноти та своєчасності відображення в системі обліку витрат, доходів і фінансових результатів. Охарактеризовано особливість організації обліку результатів діяльності підприємств у сфері надання послуг. Визначено роль бухгалтерського обліку і контролю за господарськофінансовою діяльністю підприємства в системі формування результатів діяльності підприємства. Обгрунтовано спрямування організації обліку результатів діяльності на підприємствах на забезпечення максимальної ефективності облікових процееур. Досліджено наукові погляди вітчизняних, зарубіжних вчених та норми нормативно-правових актів стосовно дефініції “зведений облік”. Розглянуто методику зведеного обліку витрат на підприємствах. Визначено послідовність організаиії та здійснення зведеного обліку витрат. Подано авторське бачення зведеного обліку витрат на підприєствах з врахуванням організаційно-технологічних особливостей діяльності в умовах застосування національних і міжнародних стандартів бухгалтерського обліку (фінансової звітності). Запропоновано форму відомості “Зведення витрат” як документ, у якому відображають: результати узагальнення обліку витрат у розрізі калькуляційних статей витрат; основних етапів діяльності підприсмства, за якими потрібно узагальнювати витрати. Досліджено наукові погляди вітчизняних, зарубіжних вчених стосовно визначення поняття “калькуляція”. Визначено місие калькулювання собівартості послуг в системі бухгалтерського обліку підприємств. Досліджено види собівартості послуг на підприємствах. Охарактеризовано особливості методів обліку витрат і калькулювання собівартості послуг на підприємствах. Доведено, щзо раціональна організація зведеного обліку витрат та калькулювання собівартості послуг являє собою методично найбільи складну й відповідальну ділянку обліку.
\end{abstract}

Ключові слова: зведений облік, калькулювання, результат, діяльність, послуга.

Redchenko K. I.,

redchenko@ukr.net, ORCIDID:0000-0001-8234-4074,

Researcher ID: F-3039-2013,

Doctor of Economics, Professor, Professor of the Department of Accounting, Control, Analysis and Taxation, Lviv University of Trade and Economics, Lviv

Chik M. Yu.,

marija_chik@ukr.net, ORCID ID: 0000-0002-8124-2276,

Researcher ID: Y-3059-2018,

Ph.D., Associate Professor, Associate Professor of the Department of Accounting, Control, Analysis and Taxation, Lviv University of Trade and Economics, Lviv

\section{CONSOLIDATED COST ACCOUNTING AS A COMPONENT OF FORMATION OF THE RESULT OF AN ENTERPRISE'S ACTIVITY}

\footnotetext{
Abstract. The article studies the problem of completeness and timeliness of costs, revenues and financial results representation in the accounting system. The peculiarity of the organization of accounting for the results of enterprise's activity in the field of services is characterized. The role of accounting and control over economic and financial activity of the enterprise in the system of formation of results of enterprise's activity is defined. The direction of the organization of the accounting for the results of enterprise's activity for ensuring maximum efficiency of accounting procedures
} 
is substantiated. The scientific views of domestic and foreign scientists as well as regulations concerning the definition of "consolidated accounting" are studied. The method of consolidated cost accounting at enterprises is considered. The sequence of organization and implementation of consolidated cost accounting is determined. The author's vision of the consolidated cost accounting at the enterprises taking into account organizational and technological peculiarities of activity in the conditions of application of national and international standards of accounting (financial reporting) is given. The form of the list "Costs Summary" as the document in which reflects: results of generalization of the cost accounting in terms of separate costing items is offered; the main stages of the enterprise's activities, for which the summarization of costs is needed, is proposed. The scientific views of domestic and foreign scientists on the definition of the concept of "calculation" are studied. The place of calculating of the services costs in the accounting system of enterprises is determined. The types of costs of services at enterprises are investigated. The peculiarities of cost accounting methods as well as calculation of services costs at enterprises are characterized. It is proved that the rational organization of the consolidated cost accounting as well as calculation of the cost of services represent methodically the most difficult and responsible part of the accounting.

Key words: consolidated accounting, calculation, result, activity, service.

JEL Classification: L26, M41

DOI: https://doi.org/10.36477/2522-1205-2020-61-10

Постановка проблеми. В умовах здійснення глобалізаційних процесів у сучасному економічному середовищі система обліку займає важливе місце, оскільки близько 70 \% інформації формується саме бухгалтерським обліком. При цьому важливою складовою такої системи $є$ зведений облік, який $є$ основою для формування собівартості продукції, визначення фінансових результатів підприємств та прийняття ефективних управлінських рішень.

Підприємства у своїй діяльності повинні застосовувати таку методику зведеного обліку витрат, що б враховувала як особливості їх господарської діяльності, так і вимоги національних і міжнародних стандартів бухгалтерського обліку (фінансової звітності).

Аналіз останніх досліджень і публікацій. Питання організації та методики зведеного обліку витрат на підприємствах різних видів економічної діяльності у своїх працях досліджували Безруких П. С., Белобородова В. А., Воронко Р. М., Івашкевич В. Б., Задорожній 3. В., Кашаєв А. Н., Куцик П. О., Палій В. Ф., Пушкар М. С., Слабінскій В. Т., Чечета А. П. Проте на сьогодні, враховуючи динаміку економічних реалій та плинність норм чинного законодавства, комплексні дослідження 3 питань зведеного обліку витрат як важливої складової системи обліку витрат в управлінні діяльністю підприємств відсутні.

Постановка завдання. Мета статті - дослідження зведеного обліку витрат на підприємствах 3 врахуванням особливостей діяльності підприємств для ефективного формування результатів діяльності підприємств.

Виклад основного матеріалу дослідження. Основною проблемою обліку результатів діяльності підприємств в Україні $з$ метою їх ефективного управління є проблема повноти та своєчасності їх відображення в системі обліку, тобто облік витрат, доходів і фінансових результатів. У даний час переважна більшість вітчизняних підприємств відображають доходи і витрати не повністю. Так, рівень не відображення доходів знаходиться в діапазоні: 30-70\%, а витрат - 10-50\%, тобто витрати відображають більш повно, ніж доходи. Це пов'язано 3 тим, що витрати важче приховувати, їх легше проконтролювати, ніж доходи, а також це дає змогу занизити “реальний” результат діяльності підприємства. Інфраструктурний характер операційної діяльності підприємств впливає на формування їх результатів, які визначаються шляхом порівняння доходів і відповідних їм витрат. Тому сьогодні важливого значення та актуальність набула проблема обліку результатів діяльності підприємств 3 метою їх ефективного управління.

Особливість організації обліку результатів діяльності підприємств полягає в тому, що він прямо пов'язаний $з$ джерелом інформації, а саме: господарськими операціями. Завдяки цьому в економічній літературі склалася така думка, що облік результатів діяльності - це підсумкова база формування всієї системи обліку. Тому вимоги до оперативності, аналітичності, економічності, розгорнутості та достовірності обліку повинні реалізовуватися на стадії обліку результатів діяльності.

У сучасних умовах господарювання організація обліку результатів діяльності на підприємствах повинна бути спрямована на забезпечення максимальної ефективності облікових процедур, що визначається найбільш повною реалізацією його інформаційної, аналітичної та контрольної функцій.

Для прийняття ефективних рішень та для нормального функціонування системи управління в цілому керівництво підприємств сфери послуг повинно мати у своєму розпорядженні оперативну, точну та вичерпну інформацію про стан об'єкта управління. Ця інформація має містити оцінку стану об'єкта. Чим вища міра інформованості, чим правильніше і раніше інформовані керівники і менеджери про величину та характер відхилень фактичних показників від нормативних або запланованих, тим ефективніше можна обрати та здійснити регулюючий вплив. 
Нагромадження облікової інформації про витрати на виконання послуг з використанням зведеного обліку витрат - це кінцевий етап формування інформаційних потоків. Навіть незначна помилка, що виникла на цьому етапі, може справити істотний вплив на фінансовий результат підприємства [1].

Підприємства мають застосовувати у своїй діяльності таку методику зведеного обліку витрат та калькулювання собівартості продукції, в якій враховуються всі особливості діяльності підприємств галузі, а також сучасні й прогнозні вимоги до формування інформаційної бази, використовуваної для прийняття ефективних управлінських рішень.

В історичному аспекті методика зведення (узагальнення) в бухгалтерському обліку за різними об'єктами відома ще 3 елліністичного періоду (334 р. до н.е. - 30 р. н.е.). У ті часи записи на рахунках бухгалтерського обліку за різними об'єктами здійснювали в хронологічному порядку, при цьому сальдо вираховували після запису кожної господарської операції. У деяких випадках дані 3 документів записували безпосередньо на рахунки, а інколи групували за однорідними господарськими операціями. Далі складали зведений документ, який узагальнював денну (місячну, квартальну) інформацію.

Дослідження впливу організаційнотехнологічних особливостей діяльності підприємства на побудову обліку витрат основної операційної діяльності показало, що раціональна організація зведеного обліку витрат та калькулювання собівартості послуг, здійснення постійного контролю за зміною собівартості окремих видів продукції являє собою методично найбільш складну й відповідальну ділянку обліку, яка залежить від багатьох чинників, а саме: належність до певної галузі; асортимент послуг, які надає підприємство; структурно-організаційна побудова управління; метод обліку витрат і калькулювання собівартості послуг.

Підприємства, здійснюючи зведений облік витрат і калькулювання собівартості послуг, керуються галузевими методичними рекомендаціями 3 формування собівартості продукції (робіт, послуг). Дослідження спеціальної економічної літератури (монографій, підручників і навчальних посібників, наукових статей) показало, що комплексних публікацій, присвячених методиці зведеного обліку витрат на калькулювання собівартості послуг на підприємствах, немає.

Вивчення літературних джерел та нормативнодовідкової бази показало, що поняття “зведений облік витрат” науковцями та практиками трактується по-різному: облік зведення витрат, зведений облік витрат, зведення витрат, узагальнення витрат.

П. С. Безруких, В. Б. Івашкевич, А. Н. Кашаєв трактують поняття зведеного обліку витрат, його цілі, завдання, кінцевою метою яких є визначення результатів діяльності, як узагальнення за об'єктами обліку витрат усіх оборотів за місяць та виявлення фактичної собівартості продукції [4]. На наш погляд, подібне формулювання зведеного обліку витрат дає В. Ф. Палій. Він визначає зведення витрат як спосіб “узагальнення собівартості кінцевих продуктів за даними аналітичного обліку витрат за об'єктами калькулювання в розрізі структурних підрозділів підприємства й центрів витрат" [8, с. 185$]$.

Провідні вчені львівської наукової бухгалтерської школи характеризують зведений облік витрат як:

- узагальнення за об'єктами обліку всіх витрат за звітний місяць на початок i кінець періоду (П. О. Куцик);

- завершальний етап у обліковій роботі, що передує калькулюванню собівартості продукції (Р. М. Воронко);

- етап завершення обліку використання ресурсів як елементів і статей витрат (К. І. Редченко).

Відповідно до методичних рекомендацій 3 формування собівартості продукції (робіт, послуг) підприємств різних видів економічної діяльності зведений облік витрат - це узагальнення за об'єктами обліку всіх витрат за місяць та витрат майбутніх періодів, калькулювання (визначення) фактичної собівартості продукції (товарів, робіт, послуг).

Не можемо погодитись із останньою дефініцією, адже процес калькулювання фактичної собівартості послуг є складовою облікової діяльності, а також на більш високому методологічному рівні окремим елементом методу бухгалтерського обліку i, відповідно, не може входити до поняття “зведений облік”. Якщо взяти за основу поетапну побудову обліку на підприємствах, то зведений облік витрат - це узагальнення витрат за об'єктами обліку з метою подальшого визначення фактичної собівартості послуг.

Зведений облік витрат є завершальним етапом обліку. Він покликаний забезпечити:

- розкриття всіх витрат за калькуляційними статтями витрат і місцями їх виникнення в розрізі груп однорідних послуг (шифрів послуг);

- отримання даних про собівартість послуг у розрізі груп однорідних послуг;

- отримання даних, необхідних для калькулювання собівартості окремих видів послуг, 3 розкриттям витрат за встановленими групами.

Його завдання - узагальнення витрат за калькуляційними статтями та елементами витрат та видами (групами) послуг з подальшим використанням цих даних для складання звітності та калькуляцій фактичної собівартості послуг [6].

Результати проведених досліджень дають змогу зробити висновок, що зведений облік витрат на підприємствах має здійснюватися в такій послідовності: узагальнюються дані обробки первинної документації, що містить інформацію про облік витрат на підприємствах за попередні звітні періоди та звітний період; на основі отриманої інформації складаються Розрахунки розподілу різних видів витрат, які стануть основою для калькулювання 
собівартості послуг; здійснюється зведення витрат й калькулювання собівартості послуг підприємств.

Документом, у якому відображають результати узагальнення обліку витрат, є запропонована форма відомості “Зведення витрат”, яка складається щоквартально. Результати дослідження методики ведення обліку витрат основної операційної діяльності на підприємствах дали змогу включити в запропоновану відомість наступну інформацію:

- калькуляційні статті витрат;

- основні етапи діяльності підприємства, за якими потрібно узагальнювати витрати.

У сучасних умовах господарювання питання калькулювання собівартості послуг посідає важливе місце в системі бухгалтерського обліку підприємств. У теорії бухгалтерського обліку калькуляція є одним із елементів методу бухгалтерського обліку, який, на нашу думку, найбільш тісно пов'язаний з таким важливим елементом, як оцінка, оскільки калькулювання є основою для грошової оцінки фактичної собівартості продукції. Калькулювання собівартості послуг - один із початкових етапів планування діяльності підприємства в умовах ринкової економіки. Визначення собівартості послуг цікавить власників підприємств, бухгалтерів і аналітиків на всіх етапах діяльності підприємства. Методика розрахунку собівартості має враховувати організаційно-технологічні особливості підприємств різних галузей промисловості.

Як вважає Evans M. Н., калькулювання - це інструмент контролю за витратами, засіб визначення економічної вигоди [2]. П. О. Куцик зазначає, що розрахунок за статтями витрат собівартості одиниці послуг називається калькуляцією [7]. На думку Openshaw K., калькуляція - це розрахунок, що має на меті визначити, в якому розмірі витрати входять у ціну послуги [4].

Ми розуміємо під формуванням собівартості (калькулюванням) процес узагальнення статей витрат, визначення загальної суми витрат і витрат одиниці послуг. Результатом процесу формування собівартості є складання калькуляції.

Дослідивши питання калькулювання собівартості послуг та узагальнивши погляди вчених, пропонуємо розглядати поняття “калькуляція" 3 урахуванням двох аспектів: калькуляція - це результат обгрунтованого розрахунку собівартості послуг; калькуляція - це засіб забезпечення інформацією, необхідною для прийняття управлінських рішень.

Оптимізація витрат основної операційної діяльності та раціональне використання природних, матеріальних, трудових i фінансових ресурсів сприяє зниженню собівартості послуг, підвищенню прибутковості та, відповідно, рентабельності підприємств. Зниження собівартості послуг - важливе завдання для керівництва підприємств, тому показнику собівартості слід приділяти особливу увагу в бюджетах підприємств.

Таким чином, повна собівартість послуг підприємств відображає всі витрати на реалізацію послуг, але менша за вартість послуги на суму податку на додану вартість. Це основна відмінність між собівартістю і вартістю створеної підприємством послуги [9].

Питання формування собівартості послуг завжди було проблемним і актуальним. Адже будьяка послуга має свою собівартість незалежно від того, чи $є$ основною діяльністю підприємства надання послуг (консалтингові компанії, IT-компанії, медійні компанії), чи надання послуг $\epsilon$ супутнім основному виду діяльності (операційна оренда, компенсація вартості комунальних послуг). Неформування собівартості в будь-якому випадку спотворює структуру витрат підприємства і призводить до неправильної їх класифікації. Наприклад, неформування собівартості під надані послуги з оренди частини приміщення призводить, як правило, до завищення адміністративних витрат i заниження інших операційних витрат, що $\epsilon$ підставою для виключення неправильно класифікованих витрат з об'єкта оподаткування податком на прибуток підприємств.

Собівартість як частина вартості є важливою складовою ціни послуги. Іншу частину ціни складають: чистий дохід підприємства (прибуток) та податок на додану вартість. Між собівартістю послуг та ціною існує нерозривний зв'язок: собівартість, яка є основою для формування ціни, $є$ важливим чинником для зниження ціни на послугу.

Проаналізувавши наукові праці вітчизняних i зарубіжних учених у галузі бухгалтерського обліку, вважаємо за доцільне виокремлювати на підприємствах такі види собівартості послуг (рис. 1).

Раціональне калькулювання собівартості послуг можливе лише за правильного вибору методів обліку витрат із урахуванням організаційнотехнологічних особливостей діяльності. Проте недосконалість визначення собівартості послуг спричиняє втрату частини інформації, змісту та призначення, викривлення суті, зниження достовірності, унеможливлення дослідження та управління.

Постає завдання якомога правильніше обліковувати витрати із застосуванням прийомів і методів організації, розроблених і вдосконалених науковцями, у поєднанні з вимогами, які диктує підприємство.

У вітчизняній і зарубіжній літературі методи обліку витрат і калькулювання собівартості послуг щораз частіше називають методами калькулювання. Evans M. Н. вважає, що метод калькулювання це сукупність способів аналітичного обліку витрат за калькуляційними об'єктами та прийомів обчислення собівартості калькуляційних одиниць [2]. На думку П. О. Куцика, методи калькулювання - це економічні прийоми визначення собівартості окремих видів послуг (об'єктів калькулювання) [7]. Openshaw K. характеризує метод обліку витрат та калькулювання собівартості послуг як єдиний процес дослідження витрат та реалізацію послуг 3 позицій вимірювання, опрацювання та контролю за цими витратами, визначення собівартості послуг [4]. 


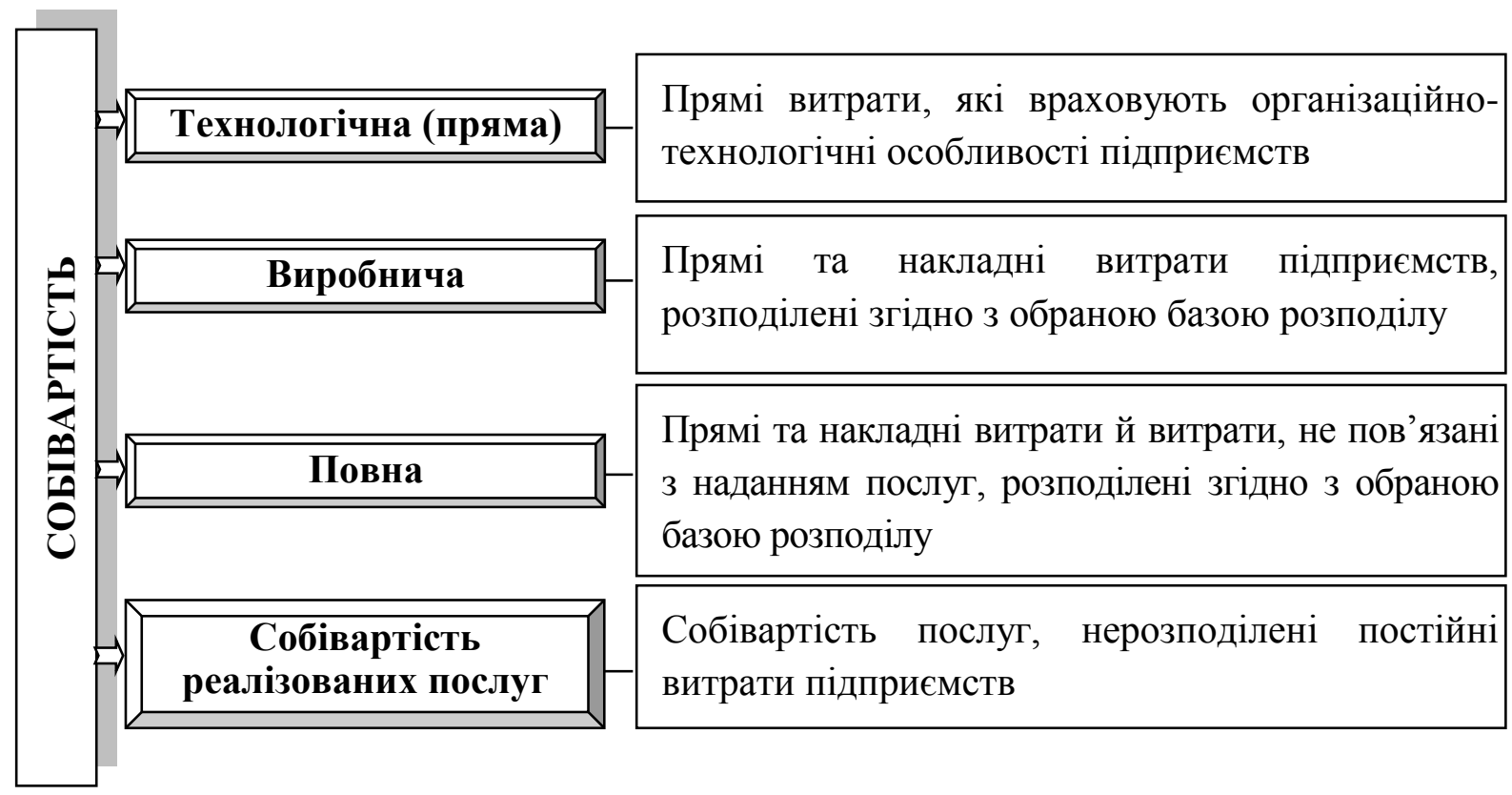

Рис. 1. Види собівартості послуг на підприємствах

Отже, загальноприйнятої класифікації методів обліку витрат і калькулювання собівартості послуг в економічній літературі не розроблено. Більшість авторів наводять власні класифікації методів обліку витрат і калькулювання собівартості послуг. В основу цих класифікацій покладено такі ознаки, як спосіб групування витрат за об'єктами обліку, ступінь оперативності контролю витрат (поточний контроль, щоденний контроль витрат за нормами чи за кінцевим результатом діяльності).

Ми вважаємо науково правильним термін "методи обліку витрат і калькулювання собівартості послуг", оскільки це пов'язані етапи у процесі підприємств, а саме: при формуванні собівартості послуг, позаяк метод обліку витрат $є$ відображенням витрат у бухгалтерському обліку, а згодом перенесення їх на відповідні статті калькуляції для визначення собівартості послуг.

Вибір методу калькулювання зобов'язує дотримуватися певних моментів, а саме: визначення об'єкта калькулювання (обліку витрат); необхідність розподілу непрямих витрат між об'єктами калькулювання; порядок розробки норм і нормативів витрат; періодичність калькулювання собівартості послуг.

Висновки i перспективи подальших досліджень у даному напрямі. Таким чином, результати проведених досліджень дають змогу зробити висновок, що зведений облік витрат на підприємствах повинен узагальнювати дані обробки первинної документації, що містить інформацію про облік витрат на підприємствах за попередні звітні періоди та звітний період. Інформаційний базис, сформований під час зведеного обліку витрат, повинен бути основою ефективного формування результатів діяльності підприємств.

\section{ЛІТЕРАТУРА}

1. Chik M. Yu. Leveraging a lean region based on blockchain technology / M. Yu. Chik, A. A. Makurin // Проблеми теорії та методології бухгалтерського обліку, контролю та аналізу. - № 3(47). 2020. - C. 62-68.

2. Evans M. H. Creating Value through Financial Management / Matt H. Evans [Електронний pecypc]. - Режим доступу : http://www.oercommons.org/ courses/creating-value-through-financialmanagement/view.

3. Openshaw K. Cost and Financial Accounting in Forestry / K. Openshaw. - Pergamon Pr, March 1980. - $202 \mathrm{p}$.

4. Безруких П. С. Бухгалтерский учет в промышленности : учебник / П. С. Безруких, В. Б. Ивашкевич, А. Н. Кашаев. - [2-е изд., перераб. и доп.]. - М. : Финансы и статистика, 1987. - 263 с.

5. Калькуляция себестоимости продукции в промышленности : учебное пособие / [В. А. Белобородова, А. П. Чечета, В. Т. Слабинский и др.]. - [2-е изд., перераб. и доп.]. - М. : Финансы и статистика, 1989. -289 c.

6. Куцик П. О. Концептуальний розвиток методології бухгалтерського обліку : монографія / П. О. Куцик, М. В. Корягін. - Львів : Видавництво Львівської комерційної академії, 2015. - 239 с.

7. Куцик П. О. Обліково-аналітична концепція управління загальновиробничими витратами підприємства : монографія / П. О. Куцик, О. М. Мазуренко. - Львів : Видавництво "Растр 7", 2014. - 288 c.

8. Палий В. Ф. Основы калькулирования / В. Ф. Палий. - М. : Финансы и статистика, 1987. $288 \mathrm{c}$.

9. Чік М. Ю. Система обліку на підприємствах лісового господарства / М. Ю. Чік // Бухгалтерський облік, аналіз та аудит: проблеми теорії, 
методології, організації : збірник наукових праць. Вип. 2(17). - Київ, 2016. - С. 238-246.

\section{REFERENCES}

1. Chik, M. Yu. and Makurin, A. A. (2020), Leveraging a lean region based on blockchain technology, Problemy teoriyi ta metodolohiyi bukhhalters'koho obliku, kontrolyu ta analizu, No. 3(47), s. 62-68.

2. Evans, M. H. (2018), Creating Value through Financial Management / Matt H. Evans, available at: http://www.oercommons.org/courses/creating-valuethrough-financial-management/view.

3. Openshaw K. (1980), Cost and Financial Accounting in Forestry, Pergamon Pr, 202 p.

4. Bezrukykh, P. S. Yvashkevych, V. B. and Kashaev, A. N. (1987), Bukhhalterskyj uchet v promyshlennosty : uchebnyk, 2 nd ed, Fynansy y statystyka, M., 263 s.

5. Kal'kulyatsiya sebestoimosti produktsii V promyshlennosti : uchebnoye posobiye, 2 nd ed,
V. A. Beloborodova, A. P. Checheta, V. T. Slabinskiy i dr. (1989), Finansy i statistika, Moskva, 289 s.

6. Kutsyk, P. O. and Koriahin, M. V. (2015), Kontseptual'nyj rozvytok metodolohii bukhhalters'koho obliku : monohrafiia, Vydavnytstvo L'vivs'koi komertsijnoi akademii, L'viv, $239 \mathrm{~s}$.

7. Kutsyk, P. O. and Mazurenko, O. M. (2014), Oblikovo-analitychna kontseptsiia upravlinnia zahal'novyrobnychymy vytratamy pidpryiemstva : monohrafiia, Vydavnytstvo “Rastr-7”, L'viv, 288 s.

8. Paliy, V. F. (1987), Osnovy kal'kulirovaniya, Finansy i statistika, Moskva, 288 s.

9. Chik, M. Yu. (2016), Systema obliku na pidpryyemstvakh lisovoho hospodarstva, Bukhhalters'kyj oblik, analiz ta audyt: problemy teorii, metodolohii, orhanizatsii : zbirnyk naukovykh prats', vyp. 2(17). s. 238-246.

Стаття надійшла до редакиіï 05 листопада $2020 \mathrm{p}$. 